\title{
$\square$

\section{PENERAPAN JARINGAN SYARAF TIRUAN DENGAN METODE PERCEPTRON UNTUK MENENTUKAN JENIS E-LEARNING (STUDI KASUS DI STMIK HANG TUAH PEKANBARU)}

\author{
Yulisman \\ Sistem Informatika, STMIK Hang Tuah Pekanbaru Hang Tuah Pekanbaru \\ Email : \\ yulismanaziera@yahoo.co.id
}

\begin{abstract}
The application of E-Learning types that correspond to the characteristics of the E-Learning system can be determined by the user by filling out a questionnaire about the characteristics of the E-Learning System. Many types of E-Learning that have been used by the institution. To determine the type of E-Learning that is appropriate to the characteristics of the E-Learning system can be done by the user by filling out the assessment questionnaire about the characteristics of the E-Learning System. The data processing results of the questionnaire to the application of the Neural Network with the Perceptron method.Neural network is an information processing system that has characteristics similar to a network of nerve biology.Perceptron is a simple network that is usually used to classify a particular type of pattern that is often known as a linear separation. From the calculations that researchers do manually or testing the train data and test data in accordance with Perceptron training steps that have been set in the equation $\mathrm{f}$ (net) $=\mathrm{t}$ (yi), and error $=0$ to determine kesusksesannya in testing data and the test data produces the correct target and in accordance with the expected results, which means that Perceptron method applied is able to predict the type of E-Learning in accordance with the characteristics of the E-Learning system is correct and generate the same target with the data from the questionnaire results from the user.Calculation of Percentage of E-Learning used STMIK Hang Tuah Pekanbaru according to the characteristics of E-Learning System Model ISO 9126 and Evaluation obtained elearning.htp.ac.id with value $-1=$ No, performance $20 \%$, and value $1=$ Yes, performance $80 \%$ and error $=0$ out of 20 training and test pattern, lecture.htp.ac.id with $-1=$ No, $45 \%$ performance, and value $1=$ Yes, performance $55 \%$ and error $=0$ of 20 data pattern training and test, edmodo.com/es3jelita with values $-1=$ No, performance $80 \%$, and value $1=$ Yes, $20 \%$ performance and error $=0$ of 20 patterns of training and test data.Based on a predetermined model and testing of train data and test data results in an appropriate and fitting test with the target $(\mathrm{f}(\mathrm{net})=\mathrm{t}(\mathrm{yi})$ ) with error value $=0$ for all entries successful for predict and determine the type of $\mathrm{E}$-Learning in accordance with the characteristics of the E-Learning system based on user rating (Lecturer) is correct and generate the same target with the actual data that is E-Learning selected by the user (Lecturer) is elearning.htp.ac.id with percentage of $80 \%$, and $20 \%$ for E-Learning implementation needs to be evaluated.
\end{abstract}

Keywords: Artificial Neural Networks, Peceptron Methode, E-Learning.

\section{Abstrak}

E-Learning adalah merupakan salah satu media pembelajaran yang memanfaatkan teknologi informasi yang didukung oleh perangkat elektronik serta jaringan internet. Banyak jenis E-Learning yang telah digunakan oleh lembaga pendidikan. Untuk menentukan jenis ELearning yang sesuai dengan karakteristik sistem E-Learning bisa dilakukan penilaian oleh user dengan mengisi kuesioner tentang karakteristik sistem E-Learning. Pengolahan data hasil dari kuesioner tersebut bisa dengan penerapan Jaringan syaraf tiruan dengan metode Perceptron. Jaringan Syaraf Tiruan adalah sistem pemrosesan informasi yang memiliki karakteristik mirip dengan jaringan syaraf biologi.Perceptron merupakan jaringan sederhana yang biasanya digunakan untuk mengklasifikasikan suatu pola tipe tertentu yang sering dikenal dengan pemisahan secara linear. Dari perhitungan yang peneliti lakukan secara manual atau pengujian terhadap data latih dan data uji yang sesuai dengan langkah-langkah pelatihan Perceptron yang sudah ditetapkan dalam persamaan $\mathrm{f}(\mathrm{net})=\mathrm{t}(\mathrm{yi})$, dan error $=0$ untuk menentukan kesusksesannya dalam pengujian data latih dan data uji menghasilkan target yang benar dan sesuai dengan hasil yang diharapkan, yang berarti bahwa metode Perceptron yang diterapkan mampu untuk memprediksi jenis E-Learning yang sesuai dengan karakteristik sistem E-Learning sudah benar dan menghasilkan target yang sama dengan data hasil kuesioner dari user. Perhitungan Persentase E-Learning yang digunakan STMIK Hang Tuah Pekanbaru yang sesuai karakteristik sistem E-Learning Model ISO 9126 dan Evaluasi didapat hasil elearning.htp.ac.id dengan nilai -1=Tidak, performance 20\%, dan nilai 1=Ya, performance $80 \%$ dan error =0dari 20 pola data latih dan uji,kuliah.htp.ac.iddengan nilai $-1=$ Tidak, performance $45 \%$, dannilai $1=$ Ya, performance $55 \%$ dan error =0dari 20 pola data latih dan uji,edmodo.com/es3jelitadengan nilai $-1=$ Tidak, performance 80\%, dannilai 1=Ya, performance $20 \%$ dan error $=0$ dari 20 pola data latih dan uji.Berdasarkan model yang sudah ditentukan dan dilakukan pengujian terhadap data latih (train) dan data uji (test) menghasilkan pengujian yang tepat dan sesuai dengan target $(\mathrm{f}(\mathrm{net})=\mathrm{t}(\mathrm{yi})$ ) dengan nilai error $=0$ untuk semua masukan telah berhasil untuk memprediksi dan menentukan jenis E-Learning yang sesuai dengan karaktersitik sistem E-Learningberdasarkan penilaian user (Dosen) sudah benar dan menghasilkan target yang sama dengan data sebenarnya yaitu E-Learningyang terpilih oleh user (Dosen) adalah elearning.htp.ac.iddengan persentase $80 \%$, dan $20 \%$ lagi untuk penerapan E-Learning perlu di evaluasi

Keywords: Jaringan Syaraf Tiruan, Metode Perceptron, E-Learning 


\section{PENDAHULUAN}

Pemanfaatan Teknologi Informasi dalam dunia pendidikan merupakan satu terobosan yang luar biasa. Dukungan teknologi informasi ini diharapkan dapat menjadi suatu inovasi dalam pembelajaran dengan banyak melibatkan komponen-komponen teknologi informasi didalamnya. Teknologi informasi berhubungan erat dengan sistem, teknologi informasi menjanjikan efisiensi, kecepatan penyampaian informasi, jangkauan yang global, fleksibel dalam penggunaannya. Oleh karena itu dalam era globalisasi sektor pendidikan pun tak luput dari jangkauannya, yaitu dengan melibatkan teknologi didalamnya dapat menghasilkan suatu sistem pendidikan (Agus Lahinta, 2012).

Adapun salah satu metode pembelajaran yang menerapkan teknologi informasi yaitu media pembelajaran secara eletronik dan online yang disebut dengan E-learning. Penelitian penerapan E-Learning menggunakan teknologi informasi dengan internet, mobile dan sistem komputer lainnya di dalam proses belajar dan mengajar, baik asynchronously atau synchronously (Mohamed Jama Madar dan Oso Willis, 2014). Penelitian yang lain menyatakan E-Learning atau Blended learning adalah pembelajaran yang mengkombinasikan antara tatap muka (antara siswa dan guru saling berinteraksi secara langsung), belajar mandiri (belajar dengan berbagai modul yang telah disediakan) serta belajar mandiri online(Dian Lestari,et al, 2016). Perguruan Tinggi (PT) baik negeri maupun swasta telah banyak menerapkan sistem E-Learning. STMIK Hang Tuah Pekanbaru merupakan salah satu perguruan tinggi swasta yang menerapkan sistem E-Learning dalam menunjang proses belajar dan mengajar. Penerapan sistem E-Learningdi STMIK Hang Tuah Pekanbaru selama ini tidak terkelola dengan baik, dan terlihat dari adanya beberapa jenis E-Learning yang digunakan, serta dari beberapa jenis E-Learning tersebut STMIK Hang Tuah Pekanbaru belum pernah melakukan peninjauan ulang atau penilaian terhadap penerapan sistemE-Learning. Ada tiga jenis E-Learning yang teridenfitikasi dan aktif digunakan oleh STMIK Hang Tuah Pekanbaru yaitu elearning.htp.ac.id, kuliah.htp.ac.id dan edmodo.com/es3jelita. E-Learning yang baik adalah yang sesuai dengan karakteristik sistem E-Learning Model ISO-9126 ditambahkan aspek evaluasi seperti evaluasi materi dll. Untuk itu perlu dilakukan penilaian E-Learning yang sesuai dengan karakteristik untuk menentukan jenis E-Learning yang di terapkan STMIK Hang Tuah Pekanbaru, dan penilaian ini dilakukan oleh dosen.

Artificial Intelligence (AI) suatu pengetahuan yang membuat komputer dapat meniru kecerdasan manusia sehingga diharapkan komputer (atau berupa mesin) dapat melakukan halhal yang apabila dikerjakan manusia memerlukan kecerdasan. Kelebihan dari Artificial Intelligence (AI) lebih bersifat permanen,
Perceptron merupakan jaringan sederhana. Perceptron biasanya digunakan untuk mengklasifikasikan suatu pola tipe tertentu yang sering dikenal dengan pemisahan secara linear. Penelitian yang terkait dengan penerapan metode perceptron dapat mempermudah dan memberikan perhitungan penyelesaian dalam menganalisa pengaruh kosmetik pada kerusakan kulit wajah (Dwyi Martha Simbolon, 2015).Penelitian yang lain penerapan perceptron mampu mengenali karakteristik sidik jari dengan baik serta mampu melakukan pelatihan dan pengujian beberapa sample objek sidik jari dengan size file yang berbeda sekalipun. (Hafizah, et al, 2015).

Berdasarkan hal tersebut di atas penelitian memfokuskan pada penerapan Jaringan Syaraf Tiruan (JST) dengan Metode Perceptron untuk menentukan jenis E-Learning, sehingga apa yang diinginkan dapat tercapai. Untuk itu pada masalah ini ada beberapa hal yang dapat dirumuskan antara lain:

1) Bagaimana kriteria dan parameter sebuah sistem ELearning untuk menentukan jenis E-learning?

2) Bagaimana menerapkan Jaringan Syaraf Tiruaan (JST) dengan metode Perceptron untuk menentukan jenis ELearning dengan aplikasi MATLAB?

Adapun tujuan yang diharapkan dalam melakukan penelitian ini agar penelitian ini bermanfaat nantinya adalah:

1) Memahami penerapan Jaringan Syaraf Tiruan (JST) dengan Metode Perceptron untuk menentukan jenis E-Learning.

2) Menganalisa penerapan E-Learninguntuk menentukan jenis E-Learning.

Melakukan pengujian datadengan aplikasi MATLAB 6.1dengan metode Perceptron untuk dijadikan model dalam menentukan jenis E-Learning.

\section{METODE PENELITIAN}

Permasalahan yang ditemukan penulis, dijabarkan dengan jelas sehingga akan terlihat inti permasalahan yang akan dibahas. Tahapan ini merupakan tahapan yang sangat menentukan untuk tahapan selanjutnya. Dalam mendeskripsikan juga ditentukan batasan permasalahan beserta ruang lingkup yang menjadi objek penelitian sehingga permasalahan menjadi terfokus pada satu titik kegiatan untuk mencapai hasil akhir sesuai dengan tujuan penelitian.

Permasalahan yang ditemukan kemudian akan dianalisa. Langkah dalam proses analisa masalah adalah langkah untuk memahami masalah yang telah ditentukan ruang lingkup atau batasan masalahnya. Dengan menganalisa permasalahan yang telah ditentukan tersebut, maka diharapkan masalah tersebut dapat dipahami dengan baik.

Langkah selanjutnya menentukan tujuan yang akan dicapai berdasarkan pemahaman dari permasalahan yang telah dianalisa. Pada tujuan ini target yang akan dicapai terutama yang 
dapat mengatasi masalah yang ada. Tujuan dari penelitian ini adalah menghasilkan suatu kriteria dan parameter sehingga dapat menentukan jenis E-Learning yang sesuai dengan karakteristik sistem E-Learning berdasarkan penilaian user (dosen).

Penelitian ini dilakukan untuk melengkapi perbendaharaan kaidah, konsep, teori - teori melalui buku, e-book, prosceding,dan jurnal - jurnal, maupun situs internet yang ada hubunganya dengan penelitian. Kemudian literatur-literatur yang dipelajari tersebut diseleksi untuk dapat ditentukan literatur mana yang akan digunakan dalam penelitian.Penelitian ini bertujuan untuk mengumpulkan data, baik data pokok maupun data pendukung, di mana semua data tersebut sangat dibutuhkan dalam penelitian.

Metode yang digunakan dalam proses pengumpulan data dalam penelitian ini adalah sebagai berikut:

a. Pengamatan (Observasi)

Metode ini merupakan salah satu langkah penyidikan yang dilakukan oleh peneliti dalam pengumpulan data yaitu dengan melakukan pengamatan langsung pada objek penelitian yaitu dengan membuka situs atau alamat domain E-Learning dan menganalisa jenis E-Learning yang digunakan oleh STMIK Hang Tuah Pekanbaru.

b. Pengisian Kuesioner

Kuisioner dibuat untuk memperoleh data hasil penilaian dari user (dosen), untuk menentukan jenis E-Learning yang sesuai dengan karakteristik sebuah sistem E-Learning. Kuesioner yang digunakan adalah kuesioner terikat, dimana responden memilih salah satu jawaban dengan tanda silang atau melingkari jawaban.

Selanjutnyaakan dilakukan analisa terhadap data yang telah terkumpul. Berdasarkan literatur-literatur yang ada, data yang didapat dari hasil, pengamatan dan pengisian kuesioner akan dilakukan pengelompokkan untuk menentukan pola data masukan (input) dan keluaran (output). Hal ini dilakukan untuk menentukan parameter, kriteria dan karakteristik sebuah ELearning yang bagus dan user friendly berdasarkan batasan-batasan yang ditetapkan dari kelompok data yang ada. Untuk menentukan variabel input dan output untuk merancang Jaringan Syaraf Tiruan (JST) dengan metode Perceptron dan dari analisa data yang telah ditentukan variabelnya berdasarkan karakteristiksistem E-Learning untuk mendapatkan hasil sebagai tujuan yang akan dicapai oleh peneliti yang kemudian dapat dijadikan pihak STMIK Hang Tuah Pekanbaru sebagai pengetahuan dalam penggunaan E-Learninghanya satu jenis, sehingga dapat digunakan secara maksimal dan efektif.

Pengujian sistem yang telah dirancang perlu dilakukan. Hal ini bertujuan untuk mengetahui apakah sistem yang dirancang tersebut sesuai dengan yang diharapkan atau tidak. Pengujian dilakukan dengan cara menetapkan pola yang sudah dibangun pada program aplikasi yang digunakan. Software pemograman yang digunakan adalah aplikasi MATLAB 6.1. Hasil yang didapatkan akan dievaluasi, apakah masalah penerapan ELearning selama ini dapat diatasi atau tidak.

\section{HASIL \& PEMBAHASAN}

\section{Analisa dan Perancangan}

Penerapan sistem E-Learning di STMIK Hang Tuah Pekanbaru selama tidak terkelola dengan baik, dan terlihat dari adanya beberapa jenis E-Learning yang digunakan, serta dari beberapa jenis E-Learning tersebut STMIK Hang Tuah Pekanbaru belum pernah melakukan peninjauan ulang terhadap penerapan sistemE-Learning. Ada tiga jenis E-Learning yang teridenfitikasi dan aktif digunakan oleh STMIK Hang Tuah Pekanbaru terlihat pada tabel 1.E-Learning yang baik adalah yang sesuai dengan karakteristik sistem E-LearningModel ISO-9126 ditambahkan aspek evaluasi seperti evaluasi materi dll. Untuk itu perlu dilakukan penilaian E-Learningyang sesuai dengan karakteristik untuk menentukan jenis E-Learning yang di terapkan STMIK Hang Tuah Pekanbaru dari aspek user (Dosen).

Tabel 1 : Karakteristik Sistem E-LearningModel ISO-9126 (Lanjutan)

\begin{tabular}{|c|c|c|}
\hline No & Karakristik & Penjelasan Karakteristik \\
\hline \multirow[t]{4}{*}{1.} & \multirow[t]{4}{*}{ Fungsi } & Kesesuaian \\
\hline & & Keakuratan \\
\hline & & In tero perabilitas \\
\hline & & Keamanan \\
\hline \multirow[t]{3}{*}{2.} & \multirow[t]{3}{*}{ Keandalan } & Kesempurnaan \\
\hline & & Toleransi kesal ah an \\
\hline & & Pemulihan \\
\hline \multirow[t]{4}{*}{3.} & \multirow[t]{4}{*}{ Kegunaan } & Dimengerti \\
\hline & & Pembelajaran \\
\hline & & Kemampuan Bekerja \\
\hline & & Menarik \\
\hline \multirow[t]{2}{*}{4.} & \multirow[t]{2}{*}{ Efisiensi } & Perilaku waktu \\
\hline & & Pemanfaatan sumber daya \\
\hline \multirow[t]{4}{*}{5.} & \multirow[t]{4}{*}{ Perawatan } & Analisa \\
\hline & & Perubahan \\
\hline & & Stabilitas \\
\hline & & Pengujian \\
\hline \multirow[t]{4}{*}{6.} & \multirow[t]{4}{*}{ Portabilitas } & Kemampuan beradaptasi \\
\hline & & Instalasi \\
\hline & & Kesesuaian \\
\hline & & Pergantian \\
\hline \multirow[t]{3}{*}{7.} & \multirow[t]{3}{*}{ Evaluasi } & Materi \\
\hline & & Tampilan Antarmuka \\
\hline & & Pedagogi \\
\hline
\end{tabular}

Sumber : IJIRSET, Vol. 5, Issue 6 (Businge Phelix Mbabazi1 dan Guma Ali, 2016) 
Tabel 2 : Jenis E-Learningyang Digunakan STMIK Hang Tuah Pekanbaru

\begin{tabular}{|c|c|}
\hline No & Jenis E-Learning \\
\hline 1 & elearning.htp.ac.id \\
\hline 2 & kuliah.htp.ac.id \\
\hline 3 & edmodo.com/es3jelita \\
\hline
\end{tabular}

Berdasarkan kedua tabel 1 dan 2 tersebutpeneliti menyusun kuesioner untuk mendapatkan penilaian user/responden terhadap jenis E-Learningyang digunakan STMIK Hang Tuah Pekanbaru. Susunan kuesioner terdiri dari petunjuk pengisian, pertanyaan kuesioner yang berbentuk tabel berdasarkan karakteristik, karakteristik penjelasan dan pertanyaan karakteristik serta 3 kolom lagi untuk jawaban dari 3 (tiga) jenis ELearning. User/responden (Dosen) dalam mengisi kuesioner didampingi oleh peneliti langsung, ini dilakukan jika ada user/responden yang tidak mengerti maksud dari pertanyaan kuesioner tersebut, user/responden bisa menanyakan langsung ke peneliti untuk mengetahui maksud dari pertanyaan kuesioner dan peneliti bisa langsung menjelaskan kepada user/responden. Cara pengisian kuesioner dengan memberikan tanda silang (X) atau melingkari (O) salah satu Jawaban A atau B dengan keterangan: A. Tidak dan B. Ya.

Setelah data terkumpul berjumlah dua 20 (dua puluh) data hasil kuesioner yang berasal dari 20 (dua puluh) user/responden (Dosen), 10 (sepuluh) adalah data hasil kuesioner penilaian Dosen terhadap E-Learning semester ganjil TA. 2016/2017 dan 10 (sepuluh) adalah data hasil kuesioner penilaian Dosen terhadap E-Learning semester ganjil Tahun Ajaran 2015/2016 sebagai analisa penggunaan jenis E-Learning sebelumnya yang pengisian kuesioner di semester ganjil TA. 2016/2017. Selanjutanya hasil kuesioner dianalisa dan dilakukan pengolahan data yang pertama di Microsoft Excel dengan menginputkan inisial dari jawaban kuesioner $:$ Tidak $=$ T dan Ya = Y.Setelah pengolahan data awal pada tabel 4.5 dan 4.6 selesai dilakukan, selanjutnya data diatas dikonversikan dari huruf ke angka. Konversi untuk huruf $\mathrm{T}=0$ dan untuk huruf $\mathrm{Y}=1$.

Selanjutnya dari data hasil kuesioner diatas peneliti mengabungan nilai/angka yang berupa 0 dan 1 di masing-masing penjelasan karakteristik dari setiap user/responden (Dosen) pada jenis E-learning untuk mendapatkan nilai (angka) karakteristik untuk menentukan jenis E-learning, yaitu dengan menghitung nilai rata-rata dari penjelasan karakteristik dan dibagi sesuai dengan jumlah penjelasan karakteristik, contoh : Karakteristik Fungsi mempunyai 4 (empat) penjelasan karaktersitik dan 4 (empat) nilai atau jawaban dari user/responden, berikut cara perhitungannya dengan Microsoft Excel :

Nilai (angka) karakteristik =Fungsi rata-rata(Nilai Penjelasan Karakteristik dari nilai (angka) setiap user)/Jumlah Penjelasan
Karakteristik

Karakteristik Fungsi $=$ Average $(1 ; 4) / 4$, Keandalan =Average $(1 ; 3) / 3$, Kegunaan=Average $(1 ; 4) / 4$, Efisiensi = Average $(1 ; 2) / 2$, Perawatan=Average $(1 ; 4) / 4$, Portabilitas= Average $(1 ; 4) / 4$, Evaluasi= Average $(1 ; 3) / 3$

Untuk perhitungan jumlah nilai jenis E-Learning per user/responden yaitu dengan menjumlahkan nilai (angka) hasil konversi jawaban masing-masing user/responden secara vertikal kemudian dibagi $7=$ jumlah karakteristik, Contoh : $1+1+1+1+1+1+1 / 7=1$ dan untuk hasil penjumlahan bilangan pecahan, maka jika $>0,5=1$ dan jika $<0,5=0$, contoh : $1+0+1+0+1+0+0 / 7=0,42=0$.

Sehingga dari perhitungan tersebut hanya ada satu nilai untuk masing-masing karakteristik.

Berdasarkan data-data yang telah dikumpulkan diatas dan diolah hingga menjadi data numerik/angka, selanjutnya kita menentukan variabel yang akan menjadi variabel masukan (input) dan keluaran/target (output).

Tabel 3 : Daftar Variabel

\begin{tabular}{|c|l|}
\hline No & \multicolumn{1}{|c|}{ Variabel } \\
\hline 1. & Fungsi \\
\hline 2. & Keandalan \\
\hline 3. & Kegunaan \\
\hline 4. & Efisiensi \\
\hline 5. & Perawatan \\
\hline 6. & Portabilitas \\
\hline 7. & Evaluasi \\
\hline 8. & Elearning.htp.ac.id \\
\hline 9. & Kuliah.htp.ac.id \\
\hline 10. & Edmodo.com/es3jelita \\
\hline
\end{tabular}

Data-data yang sudah didapatkan akan dikelompokkan menjadi 2 variabel, yaitu variabel masukan (input) dan keluaran (output).Untuk variabel masukan (input)adalah karakteristik system E-Learningdengan simbol input(Xi....n) dapat dilihat pada tabel 4 berikut:

Tabel 3 : Inisialisasi Variabel Masukan (Input)

\begin{tabular}{|c|c|}
\hline \multicolumn{2}{|c|}{ Variabel Masukkan (Input) } \\
\hline $\begin{array}{c}\text { Karakteristik Sistem E- } \\
\text { Learning }\end{array}$ & Variabel \\
\hline Fungsi & $\mathrm{X}_{1}$ \\
\hline Keandalan & $\mathrm{X}_{2}$ \\
\hline Kegunaan & $\mathrm{X}_{3}$ \\
\hline Efisiensi & $\mathrm{X}_{4}$ \\
\hline Perawatan & $\mathrm{X}_{5}$ \\
\hline Portabilitas & $\mathrm{X}_{6}$ \\
\hline Evaluasi & $\mathrm{X}_{7}$ \\
\hline
\end{tabular}

http://jik.htp.ac.id 
Untuk variabel keluaran (output) adalah jenis E-learning yang akan dijadikan sebagai target (yi) dapat dilihat pada tabel 5.

Tabel 5 :Inisialiasasi Variabel Target (Output)

\begin{tabular}{|c|c|}
\hline \multicolumn{2}{|c|}{ Variabel Target (Output) } \\
\hline Jenis E-Learning & Variabel \\
\hline elearning.htp.ac.id & $\mathrm{Y}_{1}$ \\
\hline kuliah.htp.ac.id & $\mathrm{Y}_{2}$ \\
\hline edmodo.com/es3jelta & $\mathrm{Y}_{3}$ \\
\hline
\end{tabular}

Berdasarkan tabel 4 dan 5 yaitu variabel masukan dan variabel target yang ditransformasikan ke tabel yang akan di-traindengan data hasil kuesioner berdasarkan karakteristik jenis E-learning. Sebelum data di-train dan di-testditentukan, terlebih dahuludata dinormalisasi. Adapun langkah normalisasi dilakukan dengan menjumlahkan nilai (angka) pada setiap user/responden di masing-masing jenisE-learning secara harizontal berdasarkan hasil perhitungan nilai rata-rata penjelasan karakteristik jenis ELearning. Cara perhitungan : Nilai (angka) hasil konversi jawaban user/responden ke 1/nilai karakteristik fungsi pada jenis ELearning: elearning.htp.ac.id dijumlahkan dengan nilai (angka) hasil konversi jawaban user/responden ke 1/nilai karakteristik fungsi pada jenis E-Learning :kuliah.htp.ac.id dan dijumlahkan lagi dengan nilai (angka) hasil konversi jawaban user/responden ke $1 /$ nilai karakteristik fungsi pada jenis E-Learning: edmodo.com/es3jelta, kemudian dibagi 3 sesuai dengan jumlah jenis E-Learning. Contoh : $1+1+1 / 3=1$ dan untuk hasil penjumlahan bilangan pecahan, jika $>0,5=1$, dan jika $<0,5=0$, contoh : $1+0+1 / 3=0,6666667=1$. Selanjutnya cara menentukan nilai target, yaitu dengan memindahkan Jumlah Nilai Jenis Elearning Per User/Responden secara vertikal. Tabel data berikut adalah nilai karakteristik jenis E-Learning yang telah normalisasikan dan juga transformasikan dengan variabel masukan (input) dan target (output) yang dapat dilihat pada tabel 6.

Tabel 6 :NormalisasiData dengan Variabel Jenis ELearningSemester Ganjil T.A 2015/2016

\begin{tabular}{|c|c|c|c|c|c|c|c|c|c|c|}
\hline 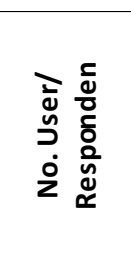 & 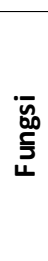 & $\begin{array}{l}\frac{1}{0} \\
\frac{\pi}{\pi} \\
\frac{\pi}{0} \\
\frac{1}{0} \\
\stackrel{0}{0}\end{array}$ & 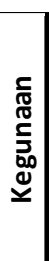 & 玄 & $\begin{array}{l}\frac{1}{70} \\
\frac{\pi}{3} \\
\frac{\pi}{0} \\
\frac{10}{2}\end{array}$ & 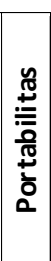 & $\begin{array}{l}\overline{5} \\
\frac{1}{2} \\
\frac{2}{10} \\
\overline{1}\end{array}$ & 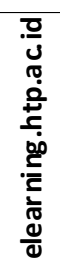 & 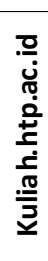 & 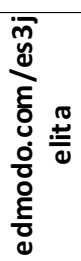 \\
\hline Variabel & $X_{1}$ & $\begin{array}{l}X \\
2\end{array}$ & $\begin{array}{l}X \\
3\end{array}$ & $\begin{array}{l}\mathrm{X} \\
4\end{array}$ & $\begin{array}{l}X \\
5\end{array}$ & $\begin{array}{l}X \\
6\end{array}$ & $\begin{array}{l}X \\
7\end{array}$ & $Y_{1}$ & $Y_{2}$ & $Y_{3}$ \\
\hline 1 & 1 & 0 & 1 & 0 & 1 & 0 & 1 & 0 & 1 & 0 \\
\hline 2 & 1 & 0 & 1 & 0 & 0 & 1 & 1 & 1 & 1 & 0 \\
\hline 3 & 0 & 1 & 1 & 1 & 1 & 1 & 0 & 1 & 1 & 0 \\
\hline 4 & 1 & 1 & 1 & 1 & 1 & 0 & 1 & 1 & 1 & 0 \\
\hline 5 & 0 & 0 & 0 & 0 & 1 & 0 & 1 & 0 & 0 & 0 \\
\hline 6 & 1 & 1 & 1 & 1 & 0 & 0 & 0 & 1 & 0 & 0 \\
\hline 7 & 1 & 0 & 1 & 1 & 1 & 0 & 1 & 1 & 0 & 0 \\
\hline 8 & 1 & 0 & 0 & 1 & 0 & 0 & 0 & 1 & 0 & 0 \\
\hline 9 & 1 & 0 & 1 & 1 & 0 & 1 & 1 & 1 & 0 & 1 \\
\hline 10 & 0 & 1 & 1 & 1 & 0 & 0 & 1 & 1 & 1 & 0 \\
\hline
\end{tabular}

Setelah menentukan input, output dan nilai bobot maka akan dilakukan pelatihan data untuk mendapatkan output. Pelatihan ini akan menggunakan Aplikasi MATLAB 6.1.

Arsitektur perceptron yang akan dibangun terdiri atas 2 (dua) lapisan yaitu lapisan masukkan yang terdiri atas 7 (tujuh) neuron unit sel masukkan (input) dan 3 (tiga) neuron sebagai target yang terlihat pada gambar 1 . Data yang di-input sebagai masukkan adalah data nilai hasil kuesioner jenis E-Learningberdasarkan karakteristik dan sebagai targetnya adalah jenis E-Learning.

Gambar arsitektur Jaringan Syaraf Tiruan Algoritma Perceptron berikut menunjukkan masukkan data berupa $x 1, x 2, x 3, x 4, x 5$, $x 6$ dan $x 7$ dengan bobot pada masing-masing $w 1, w 2, w 3, w 4$, w5, w6 dan w7 serta bias yang bernilai $b=1$. Semua data masukkan bersama bobot dan bias akan diproses ke dalam Perceptron dengan hasil berupa target y1, y2 dan y3.

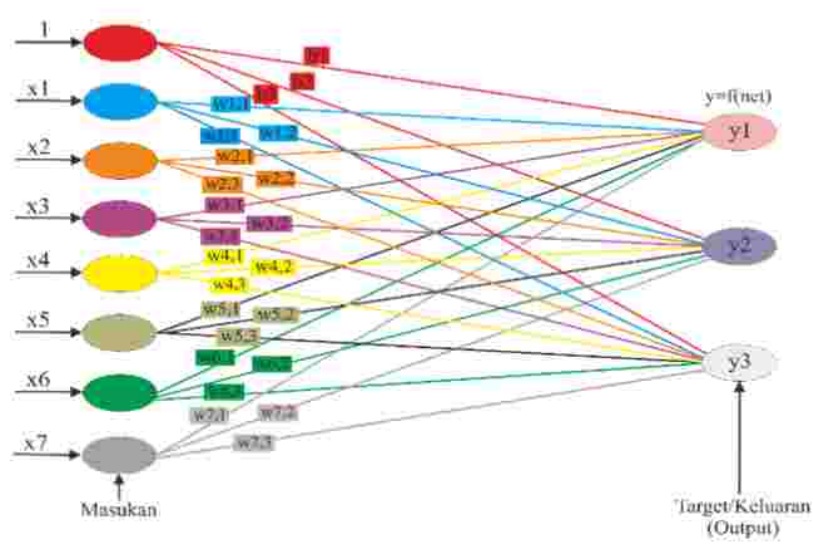

Gambar 1:Arsitektur Jaringan Perceptronuntuk Menentukan Jenis E-Learning 
Untuk mempermudah dalam proses perhitungan data-data jenis E-learning maka data harus ditransformasikan terlebih dahulu karena range keluaran fungsi aktivasi yang penulis pakai dengan keluaran $[0,1]$ untuk menentukan input-nya dan [-1,1] untuk keluaran output-nya sesuai dengan persamaan gambar 2.Setelah melakukan pengumpulan data dan dianalisa, langkah selanjutnya adalah menguji data dengan algoritma Perceptron. Sebelum melakukan pengujian data penulis terlebih dahulu merancang diagram alir untuk proses algoritma Perceptron yang akan digunakan dalam penentuan penggunaan E-Learning yang tepat.

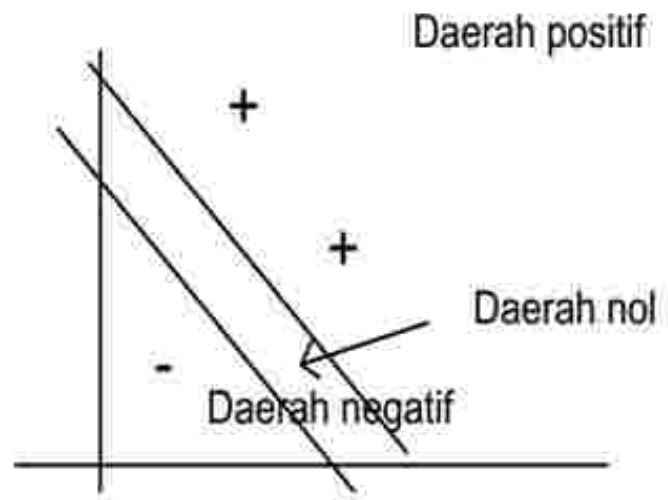

Gambar 2 :Pembatasan Linear Dengan Perceptron

Garis pemisah antara daerah positif dan daerah nol memiliki pertidaksamaan:W1X1+W2X $+b>$. Sedangkan garis pemisah antara daerah negatif dengan daerah nol memiliki pertidaksamaan:W1X1+W2X2 $+b<-$.

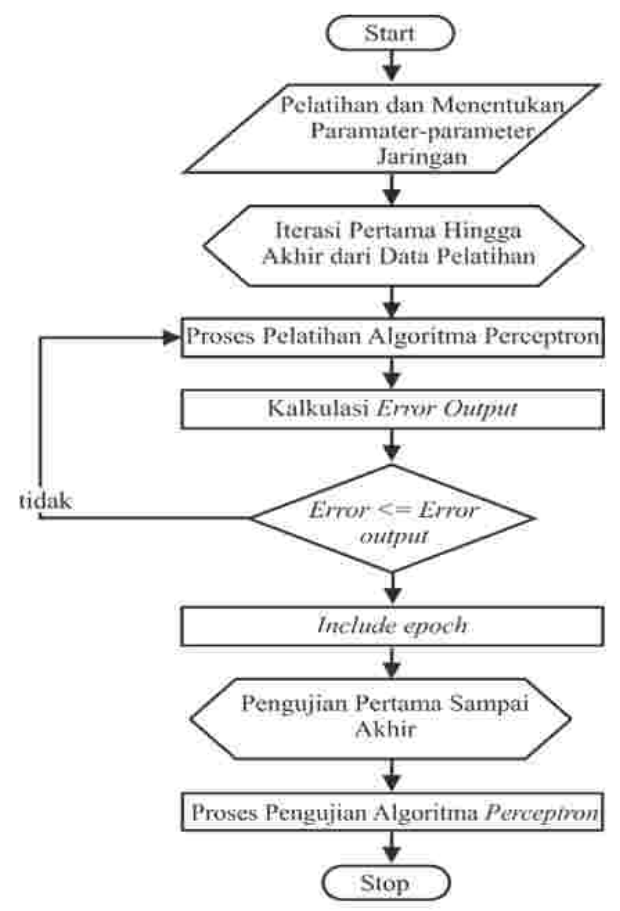

Gambar 3 : Diagram Alir Proses Algoritma Perceptron
Langkah selanjutnya yang akan dilakukan adalah melakukan perhitungan manual untuk menentukan jenis E-Learning sebagai target atau output.

Data-data di atas akan dinormalisasikan sesuai dengan pengkodean yang telah dilakukan range sebelumnya sesuai dengan persamaan pada gambar 2. Adapun perhitungan perubahan tabel 7 diatas sebagai berikut:

$$
\begin{aligned}
& \leq 0,5=0 \\
& >0,5=1 \\
& \text { Nilait(yi) adalah bipolar: } \\
& \leq 0,5=-1 \\
& >0,5=1 \\
& 0,8(x-a) \\
& X^{\prime}=\frac{}{b-a}+0,1 \\
& 0,8(1-0) \\
& X^{\prime}=\frac{}{1-0}+0,1 \\
& \text { = 0,90 ; maka hasil tersebut dibulatkan menjadi (1) }
\end{aligned}
$$

\begin{tabular}{|c|c|c|c|c|c|c|c|c|c|c|}
\hline 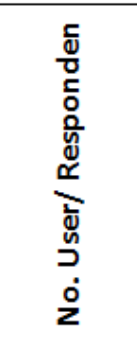 & 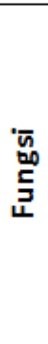 & 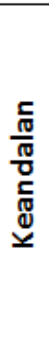 & 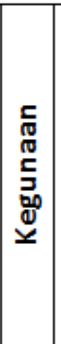 & 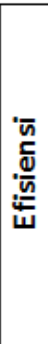 & 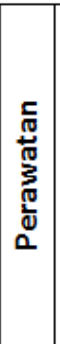 & 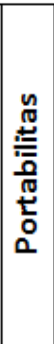 & 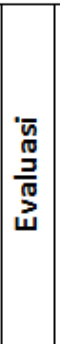 & 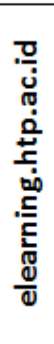 & 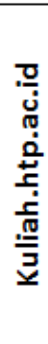 & 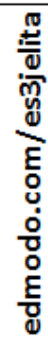 \\
\hline Variabel & $\begin{array}{l}X \\
1\end{array}$ & $\begin{array}{l}X \\
2\end{array}$ & $\begin{array}{l}\mathrm{X} \\
3\end{array}$ & $\begin{array}{l}X \\
4\end{array}$ & $\begin{array}{l}X \\
5\end{array}$ & $\begin{array}{l}X \\
6\end{array}$ & $\begin{array}{l}X \\
7\end{array}$ & $Y_{1}$ & $Y_{2}$ & $Y_{3}$ \\
\hline 1 & 1 & 0 & 1 & 0 & 1 & 0 & 1 & -1 & 1 & -1 \\
\hline 2 & 1 & 0 & 1 & 0 & 0 & 1 & 1 & 1 & 1 & -1 \\
\hline 3 & 0 & 1 & 1 & 1 & 1 & 1 & 0 & 1 & 1 & -1 \\
\hline 4 & 1 & 1 & 1 & 1 & 1 & 0 & 1 & 1 & 1 & -1 \\
\hline 5 & 0 & 0 & 0 & 0 & 1 & 0 & 1 & -1 & -1 & -1 \\
\hline 6 & 1 & 1 & 1 & 1 & 0 & 0 & 0 & 1 & -1 & -1 \\
\hline 7 & 1 & 0 & 1 & 1 & 1 & 0 & 1 & 1 & -1 & -1 \\
\hline 8 & 1 & 0 & 0 & 1 & 0 & 0 & 0 & 1 & -1 & -1 \\
\hline 9 & 1 & 0 & 1 & 1 & 0 & 1 & 1 & 1 & -1 & 1 \\
\hline 10 & 0 & 1 & 1 & 1 & 0 & 0 & 1 & 1 & 1 & -1 \\
\hline
\end{tabular}

\section{Keterangan :}

$$
\begin{array}{ll}
\mathrm{a} & : \text { Data Minimum } \\
\mathrm{b} & \text { : Data Maksimum } \\
\mathrm{x} & \text { : Nilai }
\end{array}
$$

Tabel 7 : Perubahan Data Latih (Train) Nilai Hasil Kuesioner untuk Menentukan Jenis E-Learning Semester Ganjil TA. 2015/2016

1.Implementasi dan Pengujian

a.Pengujian Data Latih

Pengujian terhadap jaringan perceptron yang telah terbentuk adalah bertujuan untuk mengetahui kecepatan perceptron untuk mengenali pola baru dari data yang akan diuji. Data yang 
akan diuji berjumlah sebanyak 10 data, dengan variabel masukan ( $x 1, x 2, x 3, x 4, x 5, x 6$ dan $x 7$ ) serta variabel keluaran/target ( $y 1, y 2$ dan y3) seperti pada tabel 8 akan diuji oleh jaringan perceptron yang telah dibangun dengan cara data di atas diuji secara keseluruhan, Hasilnya dapat dilihat pada gambar 4 .

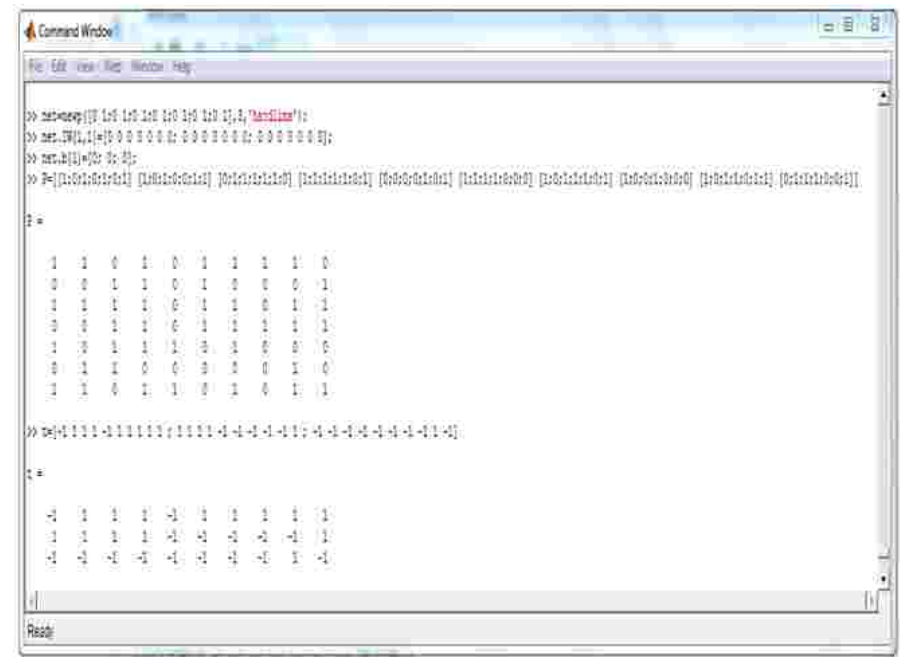

Gambar 4 : Hasil Aktivsi Pengujian 10 Pola Data Latih

Hasil keluaran dari perintah pelatihan di atas adalah berupa grafik yang menggambarkan hubungan epoch dengan performance dari pelatihan jaringan seluruh data training, menunjukkan iterasi diselesaikan dalam 14 epochs. Pada epochs1, unjuk kerja=0.4 yang artinya ada 1 pola yang sudah dikenali dengan benar. Pada epochs ke-2 (dua), unjuk kerja $=0.4$ yang berarti ada 2 pola yang sudah dikenali dengan benar. Pada epochske-3 (tiga), unjuk kerja $=0.5$ yang berarti ada 3 pola yang sudah dikenali dengan benar dan seterusnya hingga epochs ke14 yang memiliki unjuk kerja=0 yang berarti seluruh pola sudah dikenali, dapat dilihat pada gambar 5 :

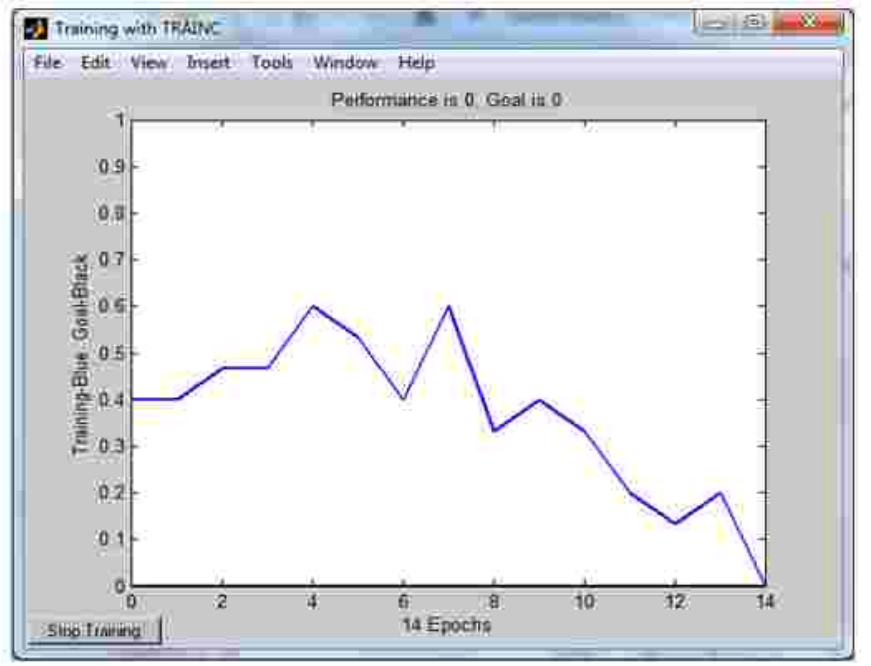

Gambar 5 : Grafik Pelatihan Pola 1 Sampai 10 Pada Data Latih
Dari hasil pengujian jaringan perceptron yang dilakukan jumlah epochsakan kecil apabila jumlah data pengujian yang digunakan sedikit yang memiliki performance yang baik yaitu $0 \%$ dan tingkat akurasi yang dihasilkan sesuai dengan yang diharapkan terlihat pada tabel dibawah ini.

Tabel 8 : Hasil Pengujian 10 (sepuluh) Pola Data Uji t1, t2 dan $\mathbf{t 3}$

\begin{tabular}{|c|c|c|c|l|}
\hline Pengujian & $\begin{array}{c}\text { Jumlah } \\
\text { Epoch }\end{array}$ & Performance & Akurasi & Ket \\
\hline 10 pola & 10 & 0 & $100 \%$ & Baik \\
\hline
\end{tabular}

\section{Pengujian Data Uji}

Pengujian terhadap jaringan Perceptron yang telah terbentuk adalah bertujuan untuk mengetahui kecepatan Perceptron untuk mengenali pola baru dari data yang akan diuji. Data yang akan diuji berjumlah sebanyak 10 data, dengan variabel masukan $(x 1, x 2, x 3, x 4, x 5, x 6$ dan $x 7)$ serta variabel keluaran/target (y1, y2dan y3), terlihat pada tabel 10. berikut:

Tabel 9 : Data Uji(Test) Nilai Hasil Kuesioner untuk Menentukan Jenis E-Learning Semester Gajil TA. 2016/2017

\begin{tabular}{|c|c|c|c|c|c|c|c|c|c|c|}
\hline 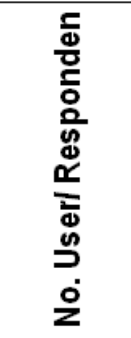 & 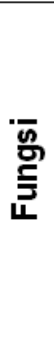 & 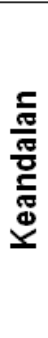 & 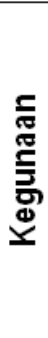 & $\frac{\bar{n}}{\frac{\bar{c}}{\omega}}$ & 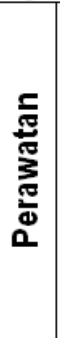 & 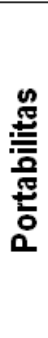 & 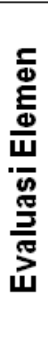 & 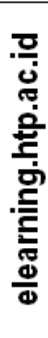 & 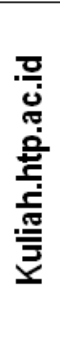 & 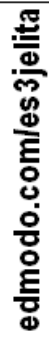 \\
\hline Variabel & $\begin{array}{l}X \\
1\end{array}$ & $\begin{array}{l}X \\
2\end{array}$ & $\begin{array}{l}X \\
3\end{array}$ & $\begin{array}{l}X \\
4\end{array}$ & $\begin{array}{l}X \\
5 \\
\end{array}$ & $\begin{array}{l}X \\
6\end{array}$ & $\begin{array}{l}X \\
7\end{array}$ & $Y_{1}$ & $Y_{2}$ & $Y_{3}$ \\
\hline 1 & 1 & 1 & 0 & 1 & 0 & 0 & 0 & -1 & 1 & 1 \\
\hline 2 & 1 & 0 & 1 & 0 & 0 & 1 & 1 & 1 & 1 & -1 \\
\hline 3 & 0 & 1 & 1 & 1 & 1 & 0 & 1 & 1 & 1 & -1 \\
\hline 4 & 1 & 1 & 0 & 0 & 1 & 0 & 1 & -1 & 1 & 1 \\
\hline 5 & 1 & 0 & 1 & 1 & 0 & 1 & 0 & 1 & -1 & -1 \\
\hline 6 & 0 & 1 & 1 & 0 & 1 & 1 & 0 & 1 & 1 & -1 \\
\hline 7 & 1 & 0 & 1 & 1 & 1 & 0 & 1 & 1 & -1 & -1 \\
\hline 8 & 1 & 0 & 1 & 1 & 0 & 0 & 1 & 1 & 1 & -1 \\
\hline 9 & 1 & 1 & 1 & 1 & 0 & 1 & 0 & 1 & -1 & 1 \\
\hline 10 & 0 & 1 & 0 & 1 & 0 & 1 & 1 & 1 & -1 & -1 \\
\hline
\end{tabular}

Selanjutnya kita lakukan pengujian data uji (test) secara keseluruhan untuk menguji jaringan perceptron yang sudah terbentukadalah bertujuan untuk mengetahui kecepatan perceptron untuk mengenali pola baru dari data yang akan diuji. Data yang akan diuji berjumlah sebanyak 10 data, dengan variabel masukan $(x 1, x 2, x 3, x 4, x 5, x 6$ dan $x 7)$ serta variabel keluaran/target (y1, y2dan y3)seperti pada tabel 11 berikut hasil pengujian pada gambar berikut: 


\section{Gambar 4 : Hasil Aktivasi Pengujian 10 Pola Data Uji}

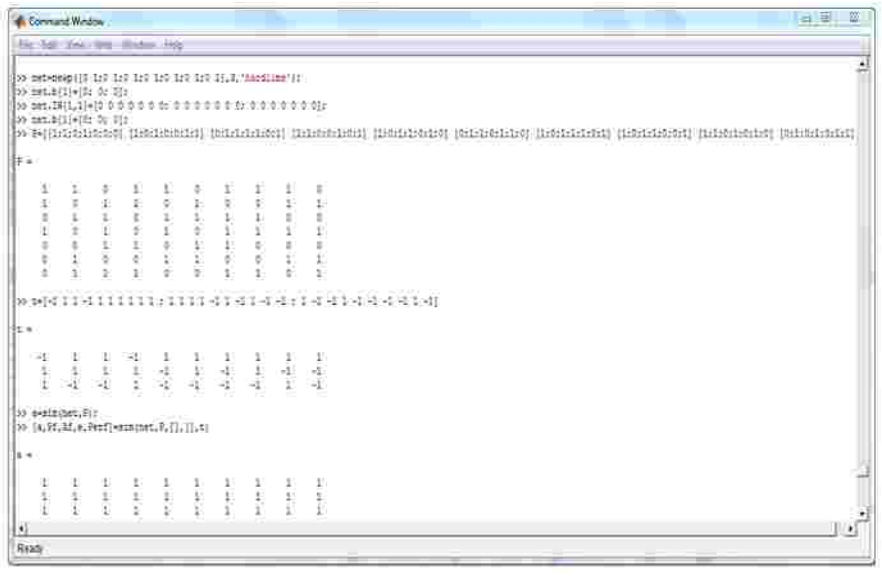

Hasil keluaran dari perintah pengujian di atas adalah berupa grafik yang menggambarkan hubungan epoch dengan performance dari pengujian jaringan seluruh data testing, menunjukkan iterasi diselesaikandalam 10 epochs. Pada epochs1, unjuk kerja=0.86 yang artinya ada 1 pola yang sudah dikenali dengan benar. Pada epochs ke-2 (dua), unjuk kerja $=0.66$ yang berarti ada 2 pola yang sudah dikenali dengan benar. Pada epochs ke-3 (tiga), unjuk kerja $=0.33$ yang berarti ada 3 pola yang sudah dikenali dengan benar dan seterusnya hingga epochs ke10 yang memiliki unjuk kerja=0 yang berarti seluruh pola sudah dikenali, dapat dilihat pada gambar 12 :

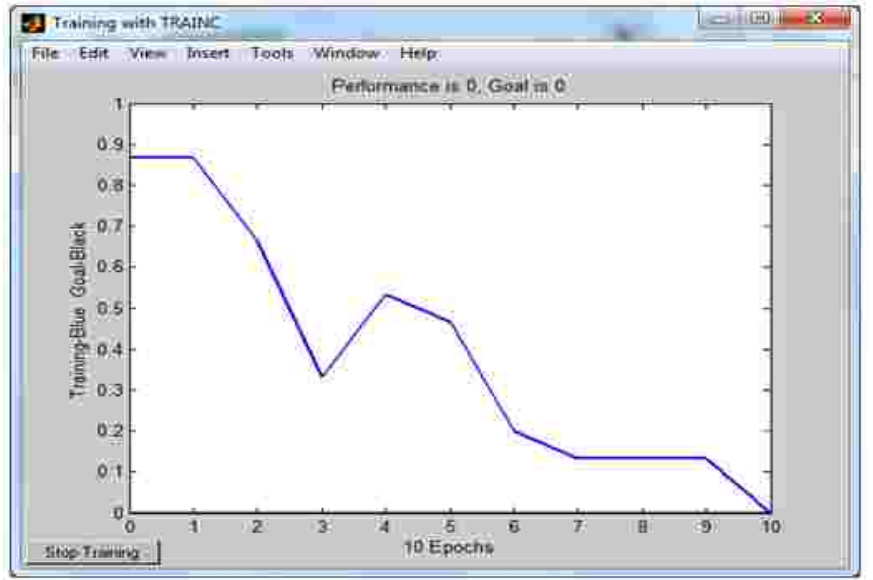

Gambar 5 : Grafik Pengujian Pola 1 Sampai 10 Pada Data Uji

\section{SIMPULAN DAN SARAN}

Pengujian yang dilakukan pada bab ini berfungsi untuk menguji Jaringan Syaraf Tiruan dengan metode Perceptron untuk mengenali kasus dengan menggunakan MATLAB dalam menentukan jenis E-Learning yang sesuai dengan karakteristik sistem E-Learning berdasarkan penilaian oleh user/responden (dosen) melalui kuesioner dengan jawaban tertutup (Ya dan Tidak), dandari hasil proses perhitungan di atas, dapat ditarik kesimpulan, di antaranya;
1.Pengujian data latih (train) untuk menentukan jenis E-Learning dengan metode perceptronyang sesuai dengan karakteristik sistem E-Learning berdasarkan penilaian oleh user/responden melalui kuesioner penulis lakukan ini dapat membantu STMIK Hang Tuah Pekanbaruuntuk menggunakan jenis ELearningyang tepat, sehingga STMIK Hang Tuah Pekanbaru dapat memaksimalkan penerapan dengan satu E-Learning saja selanjutnya.

2.Perhitungan hasil dari data uji (test) dari iterasi per pola dengan 2 epochs yang dilakukan untuk menentukan jenis E-Learning setelah semua pola dikenali dan sesuai outputf(net)=target (y1, y2 dan y3):

a.elearning.htp.ac.id bernilai output $=-1$ (Tidak), memiliki performance $=2 / 10=0,2 \times 100 \%=20 \%$,output $=1$ (Ya), memiliki performance $=8 / 10=0,8 \times 100 \%=80 \%$ dan berarti masukan yang dikenal 10 (sepuluh) pola denganerror $=0$, maka pelatihan jaringan perceptron dihentikan.

b. kuliah.htp.ac.id bernilai output $=-1$ (Tidak), memiliki performance $=4 / 10=0,4 \times 100 \%=40 \%$,output $=1(\mathrm{Ya})$, memiliki performance $=6 / 10=0,6 \times 100 \%=60 \%$ dan berarti masukan yang dikenal 10 (sepuluh) pola dengan error $=0$, maka pelatihan jaringan perceptron dihentikan.

c. edmodo.com/es3jelita bernilai output $=-1$ (Tidak), memiliki performance $=7 / 10=0,7 \times 100 \%=70 \%$,output $=1(\mathrm{Ya})$, memiliki performance $=3 / 10=0,3 \times 100 \%=30 \%$ dan berarti masukan yang dikenal 10 (sepuluh) pola denganerror $=0$, maka pelatihan jaringan perceptron dihentikan.

Berdasarkan model yang sudah ditentukan dan dilakukan pengujian terhadap data latih (train) dan data uji (test) menghasilkan pengujian yang tepat dan sesuai dengan target $(f(n e t)=t(y i))$ dengan nilai error $=0$ untuk semua masukan. Ini membuktikan bahwa jaringan Perceptron yang telah selesai melakukan pembelajaran dengan Perceptron mempunyai ketepatan yang akurat dalam mengenali semua pola model masukan dan iterasi per pola akan berhenti sampai epochs 2 (dua) karena nilai error $=0$ dan semua pola masukan sesuai dengan target yang diinginkan dan metode Perceptron yang diterapkan mampu untuk menentukan jenis E-learningdari penilaian user (Dosen) yang sesuai dengan karakteristik sistem ELearning sudah benar dan menghasilkan target yang sama dengan data sebenarnya dan jenis E-Learningyang terpilih pada pelatihan data uji adalah elearning.htp.ac.id dengan persentase $80 \%$ dan $20 \%$ E-Learning perlu dievaluasi.

\section{DAFTAR PUSTAKA}

Abdul Kadir, dan Terra Ch. Triwahyuni. (2013). "Pengantar Teknologi Informasi." Penerbit Andi : Yokyakarta.

Agus Lahinta. (2012). "Berbagai Inovasi Pembelajaran dengan Dukungan Teknologi Informasi." Seminar 
Internasional APTEKINDO. 9-15. ISSN : 1907-2066.

Ankita Potode dan Poonam Manjare. (2015). "E-Learning Using Artificial Intelligence." International Journal of Computer Science and Information Technology Reseach. Vol. 3, Issue 1, 78-82, ISSN : 2348-1196.

Anna Plichta. (2011). "The E-Learning System With Embedded Neural Network." Artificial Intelligence Application to Business and Engineering Domains." Rzeszow-Sofia, Paland-Bulgaria, ISBN : 978-954-1600559 (printed) 978-954-16-00559 (online).

Anung Rachman, et al. (2010). "Agen Cerdas Animasi Wajah untuk Game Tebak Kata". Jurnal Teknologi Informasi, Volume 6 Nomor 1, 1-8. ISSN :1414-9999.

Armin dan Ali Abrar. (2015). "Blended Learning, Implementasi E-Learning DI Politeknik Negeri Balikpapan". Jurnal Sains Terapan, No. 1, Vol. 1, 4853, ISSN : 2406-8810.

Businge Phelix Mbabazi1 dan Guma Ali. (2016). "Evaluation of E-Learning Management Systems by Lecturers and Students in Ugandan Universities: A Case of Muni University". IJIRSET, Vol. 5, Issue 6, Juni 2016, 9529-9536, ISSN(Online): 2319-8753ISSN (Print): 2347-6710.

Chrisna Atmadji dan M. Arief Soeleman. (2010). "Multimedia PembelajaranMata Kuliah Sistem Informasi Manajemen".Jurnal Teknologi Informasi, Volume 6 Nomor 1, 56-72. ISSN 1414-9999.

Dian Lestari,et al. (2016). "Pengembangan Perangkat Blended Learning Sistem Saraf Manusia untuk Meningkatkan Keterampilan Berpikir Kritis". Journal of Innovative Science Education. 5 (1). 83-93. p-ISSN : 2252-6412, e-2502-4523.

Dwyi Martha Simbolon. (2015). “Jaringan Syaraf Tiruan Analisa Pengaruh Kosmetik pada Kerusakan Kulit Wajah Menggunakan Metode Perceptron." Pelita Informatika Budi Darma, Volume : IX, Nomor : 3. 107111. ISSN : 2301-9425.

Elena Susnea. (2010). "Using Artificial Neural Networks In E-LearningSystems". UPB Scien Bulletin, Series C: Electrical Engineering. Vol. 72, Iss. 4, ISSN : 1545$234 x$.

H. M. Mustafa, dan Saeed M Badran. (2011). "On Assessment of Brain Function Adaptability in Open Learning Systems Using Neural Networks Modeling (Cognitive Styles Approach)". Journal of American Science 7 (9), 238-247, ISSN : 1545-1003.

Hafizah,et al. (2015). "Penerapan Jaringan Syaraf Tiruan dengan Algoritma Perceptron untuk mendeteksi Karakteristik Sidik Jari". Jurnal SAINTIKOM. Volume 14, No. 2, ISSN : 1978-6603.
Hartantri, F. R. dan Pujiyanta, A. (2014). “Deteksi Penyakit dan Serangan Hama Tanaman Buah Salak Menggunakan Jaringan Syaraf Tiruan (JST) dengan Metode Perceptron". Jurnal Sarjana Teknik Informatika. Volume 2, Nomor 2, 1228-1240, ISSN: 2338-5197.

Herman Dwi Surjono. (2013). "Membangun Course ELearning Berbasis Moodle Edisi Kedua. UNY Press: Yogyakarta.

Jong Jek Siang. (2009). "Jaringan Syaraf Tiruan dan Pemrograman Menggunakan Matlab/ADI". Penerbit Andi : Yokyakarta.

Merry Agustina. (2013). "Pemanfaatan E-Learning Sebagai Media Pembelajaran". SNATI, G8-G12, ISSN :19075022.

Mohamed Jama Madar danOso Willis. (2014). "Strategic Model Of Implementing E-Learning".International Journal Of Scintific \& Technology Research. Volume 3. ISSUE 5. 235-238. ISSN : 2277-8616.

Mohammad Yazdi. (2012). “E-Learning Sebagai Media Pembelajaran Interaktif Berbasis Teknologi Informasi". Jurnal IImiah Foristek, Vol. 2, No. 1.

Numiek Sulistyo Hanum. (2013). "Keefektifan E-Learning Sebagai Media Pembelajaran (Studi Evaluasi Model Pembelajaran E-Learning SMK Telkom Sandhy Putra Purwokerto)".Jurnal Pendidikan Vokasi, Vol 3, Nomor 1.

Parminder Kaur, et al. (2012). "Improving E-Learning with Neural Networks". International Journal of Computing \& Business. ISSN : 2226-6166.

Samy Abu Naser, et al. (2015). "Predicting Student Performance Using Artificial Neural Network: inthe Faculty of Engineering and Information Technology". International Journal of Hybrid Information Technology. Vol.8, No.2, ISSN: 1738 9968.

Viktor Artemenko. (2014). "Agent-Based Modeling of TheLearning Users' Behavior". International Journal of Computing. 13 (1). 61-69. ISSN : 1727-6209. 